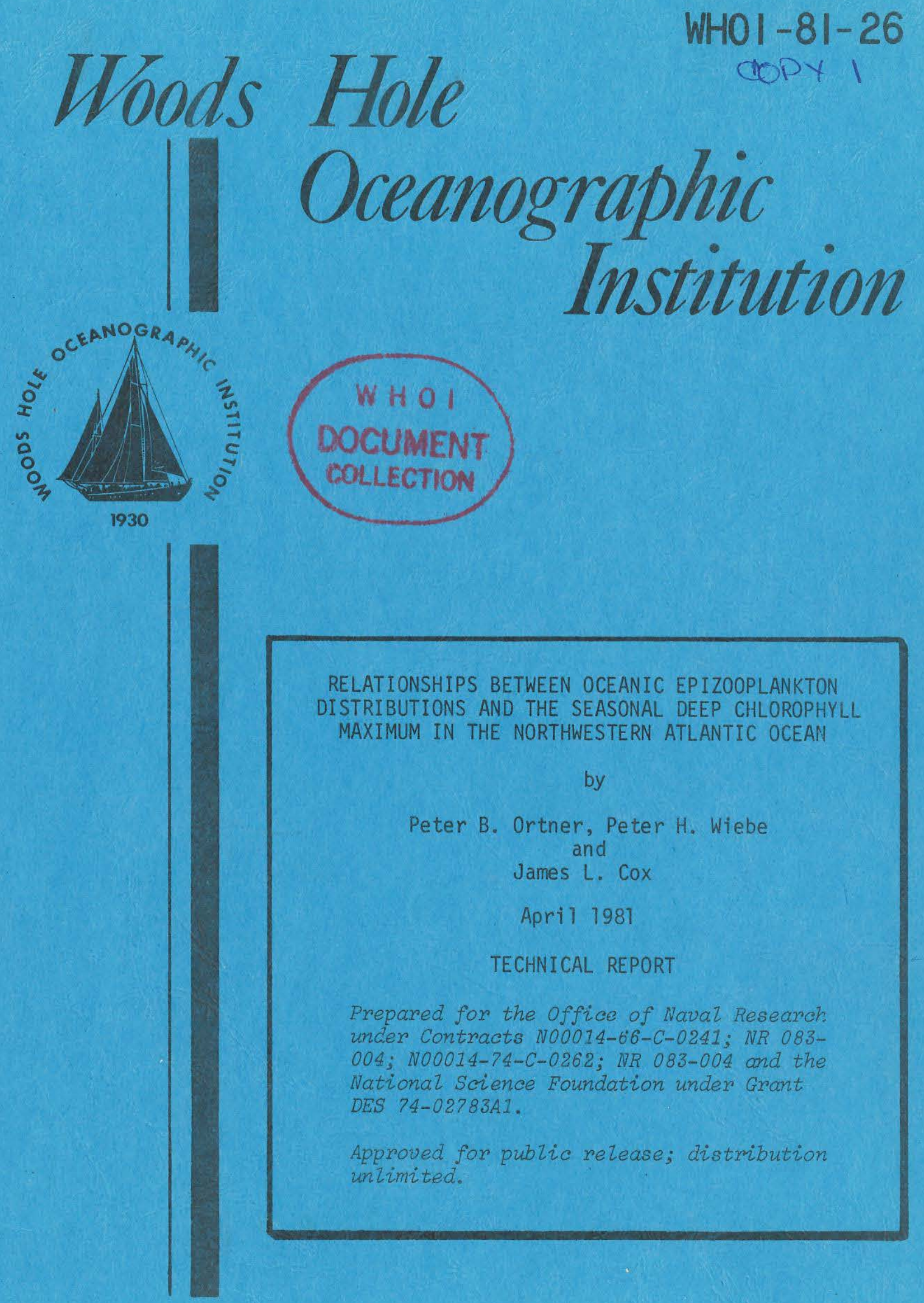

IVOODS HOLE, MASSACHUSETTS 02543 
WHOI $-81-26$

\begin{abstract}
RELATIONSHIPS BETWEEN OCEANIC EPIZOOPLANKTON
DISTRIBUTIONS AND THE SEASONAL DEEP CHLOROPHYLL MAXIMUM IN THE NORTHWESTERN ATLANTIC OCEAN
\end{abstract}

by

Peter B. Ortner, Peter H. Wiebe and James L. Cox

WOODS HOLE OCEANOGRAPHIC INSTITUTION Woods Hole, Massachusetts 02543

Apri1 1981

TECHNICAL REPORT

Prepared for the Office of Naval Research under Contracts N00014-66-C-0241; NR 083-004; N00014-74-C-0262; NR 083-004 and the National Science Foundation under Grant DES $02783 A 1$.

Reproduction in whole or in part is permitted for any purpose of the United States Government. In citing this report in a bibliography, the reference given should be to: Journal of Marine Research 38(3): 507-531 (1980).

Approved for public release; distribution unlimited.

Approved for Distribution: George D. Grice, Chairman, Department of Biology 


\title{
Relationships between oceanic epizooplankton distributions and the seasonal deep chlorophyll maximum in the Northwestern Atlantic Ocean
}

\author{
by Peter B. Ortner ${ }^{1}$, Peter H. Wiebe ${ }^{2}$, and James L. Cox ${ }^{3}$
}

\begin{abstract}
The potential significance of the Deep Chlorophyll Maximum (DCM) as a food resource for pelagic food chains was studied in three hydrographic regimes of the Northwestern Atlantic Ocean: the Slope Water, the Northern Sargasso Sea and a Gulf Stream cold core ring. Samples for phytoplankton species, chlorophyll and related water chemistry were obtained with a series of water bottle casts from the upper $200 \mathrm{~m}$; microzooplankton and macrozooplankton were also obtained in the upper $200 \mathrm{~m}$ with Clarke Bumpus $(67 \mathrm{~m}$ mesh) and MOCNESS (333 m mesh) net systems. Samples were obtained in the summer when the DCM was well developed and in the fall when mixing had erased the DCM in most areas.

Total zooplankton biomass was significantly enhanced within depth intervals including or adjacent to the seasonal thermocline in the three hydrographic areas. Hydrocast data show the DCM in these regions was predictably associated with the seasonal thermocline. Thus these data indicate zooplankton biomass was enhanced about the DCM when it was present. In some cases, the zooplankton assemblage at DCM depths was distinguishable from those both at deeper and more shallow depths and its composition appeared related to the food available at DCM depths. Overall, in environments ranging from moderately rich near-shore Slope Waters to the more oligotrophic open-ocean Sargasso Sea, our data suggest that the DCM signals a depth zone of particularly intense trophic activity.
\end{abstract}

\section{Introduction}

Seasonal accumulations of chlorophyll at the bottom of the euphotic zone have been shown to be characteristic features of three distinct hydrographic regimes in the western North Atlantic Ocean; the Slope Water, the Northern Sargasso Sea, and Gulf Stream cold core rings, whenever the upper water column remained reasonably well-stratified for an extended period of time (Ortner, 1978). This phenomenon has been called the Deep Chlorophyll Maximum (DCM) (Venrick,

1. Ocean Chemistry Laboratory, NOAA/AOML, 15 Rickenbacker Causeway, Miami, FL, 33149, U.S.A.

2. Woods Hole Oceanographic Institution, Woods Hole, MA, 02543, U.S.A.

3. Oceanic Biology Group, Marine Science Institute, University of California, Santa Barbara, Santa Barbara, CA, 93106, U.S.A. 
et al., 1973). A number of investigators have reported zooplankton species apparently associated with the depth of a DCM (Anderson, et al., 1972; Mullin and Brooks, 1972; Hobson and Lorenzen, 1972; Chester, 1975; Beers and Stewart, 1967; Youngbluth, 1975; Gunderson, et al., 1976; Haury, 1976; Fairbanks, Wicbe, and Be, 1980). However, in no case were detailed vertically stratified samples of both macrozooplankton and microzooplankton concurrently obtained. On the other hand, Venrick, et al. (1973) and Longhurst (1976) reported no such association in oligotrophic areas in the Pacific Ocean.

The work of Boyd (1973), Harder (1968), and others has indicated that zooplankton can exhibit considerable sensitivity to temperature gradients. Data presented here indicate the existence of a relationship between the North Atlantic DCM and the vertical temperature distribution. Considering the low concentration of phytoplankton biomass in the mixed layer, relative to the DCM, during times of thermal stratification (Ortner, et al., 1979), it would not be unreasonable to anticipate that zooplankton vertical distributions might respond to temperature as a DCM cue.

The principle objective of this paper will be to compare $0-200 \mathrm{~m}$ vertical distributions of zooplankton to $0-200 \mathrm{~m}$ temperature and density distributions to see if there are zooplankton biomass peaks at or about the same depth as the DCM, and to see if the structure of the zooplankton assemblage at those depths is different from the assemblage above and below. Both zooplankton data and water column properties will initially be related to vertical temperature structure, thus reducing biological variability directly attributable to hydrographic variability. This indirect approach is necessary because water bottle casts and net tows, were not synoptic.

\section{Methods}

The data presented in this paper were collected from the Northwestern Atlantic Ocean on R.V. Chain Cruise 125 (August 1975) and on R.V. Knorr Cruise 53 (November 1975). In addition to sampling the Slope Water and Northern Sargasso Sea, on both of these cruises the same ring (Ring D) was sampled. It had formed in February 1975 and was, therefore, about six months old in August and nine months old in November. The positions of sample collection are shown in Figure 1.

Collections were made with two different types of sampling gear; a multiple opening/closing net and environmental sensing system, MOCNESS (Wiebe, et al., 1976), with a mouth area of $1 \mathrm{~m} \times 1.4 \mathrm{~m}$ (effective area is $1 \mathrm{~m}^{2}$ ), and ClarkeBumpus samplers with a mouth area of $.012 \mathrm{~m}^{2}$. The MOCNESS nets were constructed with $333 \mathrm{~m}$ Nitex nylon gauze, while Clarke-Bumpus nets were made of $67 \mathrm{~m}$ nylon gauze. Depth recorders and flow meters were used on all tows.

Both MOCNESS and the Clarke-Bumpus devices sampled obliquely from 200 


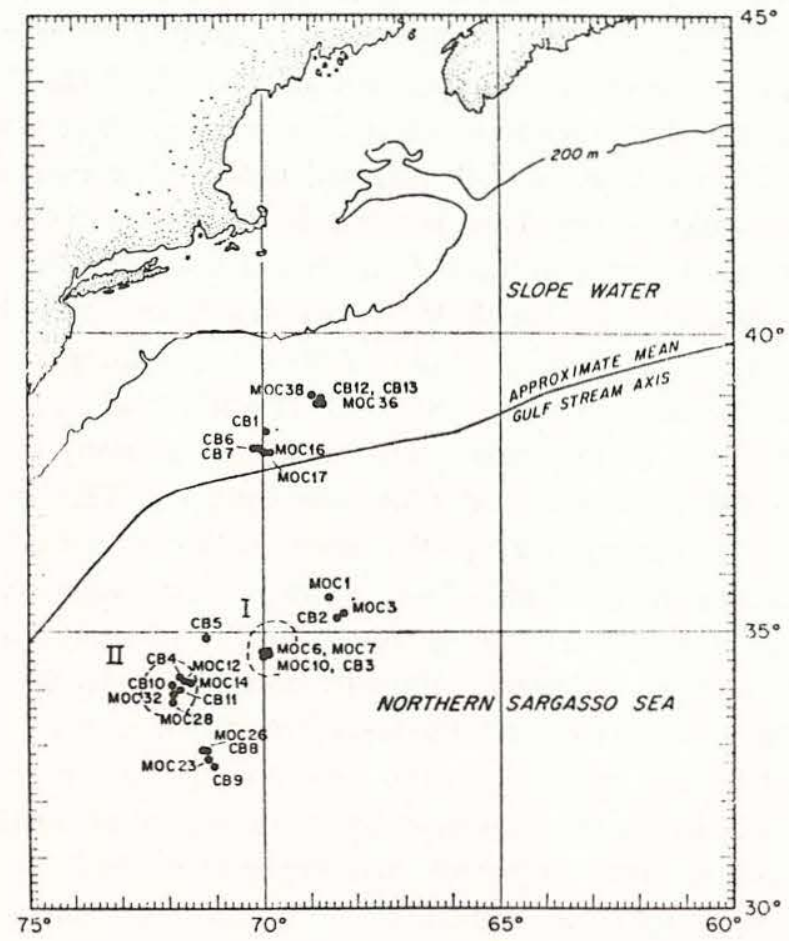

Figure 1. Positions of zooplankton tows. I, II indicate approximate Gulf Stream cold core ring boundaries on Chain 125, and Knorr 53, respectively. Note stations CB 4, MOC 12, and MOC 14 were not taken in a ring because, at that time, ring D was at position I.

$\mathrm{m}$ to the surface in $25 \mathrm{~m}$ intervals. ${ }^{4}$ Collections were made during both day and night. Five Clarke-Bumpus samplers were placed on the hydrowire at $36 \mathrm{~m}$ intervals-i.e., $25 \mathrm{~m}$ sampling intervals, assuming a constant $45^{\circ}$ wire angle-and opened by dropping a messenger when the topmost net had reached sampling depth. The nets were lowered and raised obliquely and were closed by dropping a second messenger when the topmost net had reached its starting depth. On each station, two casts were made, $0-125 \mathrm{~m}$ and $75-200 \mathrm{~m}$. When all nets functioned properly, the $75-100 \mathrm{~m}$ and $100-125 \mathrm{~m}$ depth intervals were sampled twice at every station. Ship speed for all tows was closely monitored and kept at approximately two knots. All samples were preserved in 5\% to $10 \%$ formalin buffered to $\mathrm{pH}>8.0$ with sodium tetraborate.

Zooplankton biomass in MOCNESS and Bongo samples was measured by displacement volume (Ahlstrom and Thrailkill, 1963). After biomass determination, some of the samples were sorted for species identification. In most cases, $\mathrm{cm}^{3} / \mathrm{m}^{3}$

4. MOCNESS tows to $800 \mathrm{~m}$ were taken at the same stations and are discussed in Ortner et al. (1978). 
were converted to $\mathrm{mg} \mathrm{C} / \mathrm{m}^{3}$ according to equation number one in Table 2 of Wiebe et al. (1975). Salp-rich samples were converted to biomass by assuming salps constitute $100 \%$ of the sample, salps are $99 \% \mathrm{H}_{2} \mathrm{O}$ (L. P. Madin, personal communication), and salp tissue averages $23 \%$ carbon (Silver, 1971) when dried. Such samples are identified in both text and figures. The biomass calculation for salp-dominant samples used here resulted in biomass estimates close to those obtained by measuring each individual salp in a sample, applying an experimentally determined species-specific length to carbon regression, and then summing the individual contributions (Wiebe, et al., 1979). Clarke-Bumpus samples were subdivided with a Folsom plankton splitter (McEwen, et al., 1954). An aliquot of each Clarke-Bumpus samples was filtered at $60^{\circ}$ in a drying oven, and its weight determined by difference after water loss was complete. This value was converted to $\mathrm{mg} \mathrm{C} / \mathrm{m}^{3}$ by the appropriate equation given in Wiebe, et al. (1975).

Larger organisms in the Clarke-Bumpus samples, i.e., large copepods ( $>1 \mathrm{~mm})$, medium copepods, $(0.5-1 \mathrm{~mm})$, large ostracods $(>0.5 \mathrm{~mm})$, cuphausiids, coelenterates, chactognaths, larvaceans (largely appendicularians), amphipods, polychaetes, mysids, decapods, and molluscs (mostly pteropods but, occasionally, heteropod and benthic mollusc larvae), were counted at low magnification $(25 \times)$ in the entire sample. Smaller and more abundant organisms in the Clarke-Bumpus tows, i.e., nauplii, small copepods and copepodites $(0.5 \mathrm{~mm})$, dinoflagellates (largely Ceratium spp.), foraminiferans, and tintinnids were stained with Rose Bengal and counted at moderate magnification $(50 \times)$ in an aliquot drawn by Stempel pipette. The estimate of total counting error derived from replicate subsample counts was approximately $15 \%$ (Ortner, 1978).

Temperature and salinity profiles accompanied each tow with MOCNESS, since it was equipped with its own CTD (Brown, 1974). For Clarke-Bumpus tows, the temperature structure had to be estimated from the nearest XBT (expandable bathythermograph) or CTD profile. These profiles, while not synoptic, were taken within one hour of the tow, close to the same position.

At the stations where zooplankton sampling was conducted (Fig. 1), water bottle casts were also taken, and the following parameters determined: temperature, salinity, $\mathrm{NO}_{3}, \mathrm{NO}_{2}, \mathrm{O}_{2}$, chlorophyll $a$, phaeophytin, ATP, ${ }^{14} \mathrm{C}$ uptake rate, and phytoplankton species counts. Not all of these parameters are discussed here, but appear in part in Ortner, et al. $(1978,1979)$.

\section{Vertical distributions of water column properties}

In all hydrographic regimes sampled on Chain 125 (August 1975), strong stratification began at or near the surface (see Fig. 2). In all regions, a deep chlorophyll maximum was present near the base of the most strongly stratified zone (Northern Sargasso Sea, 25-100 m; Ring D, 25-100 m; Slope Water, 0-70 m). The DCM was 

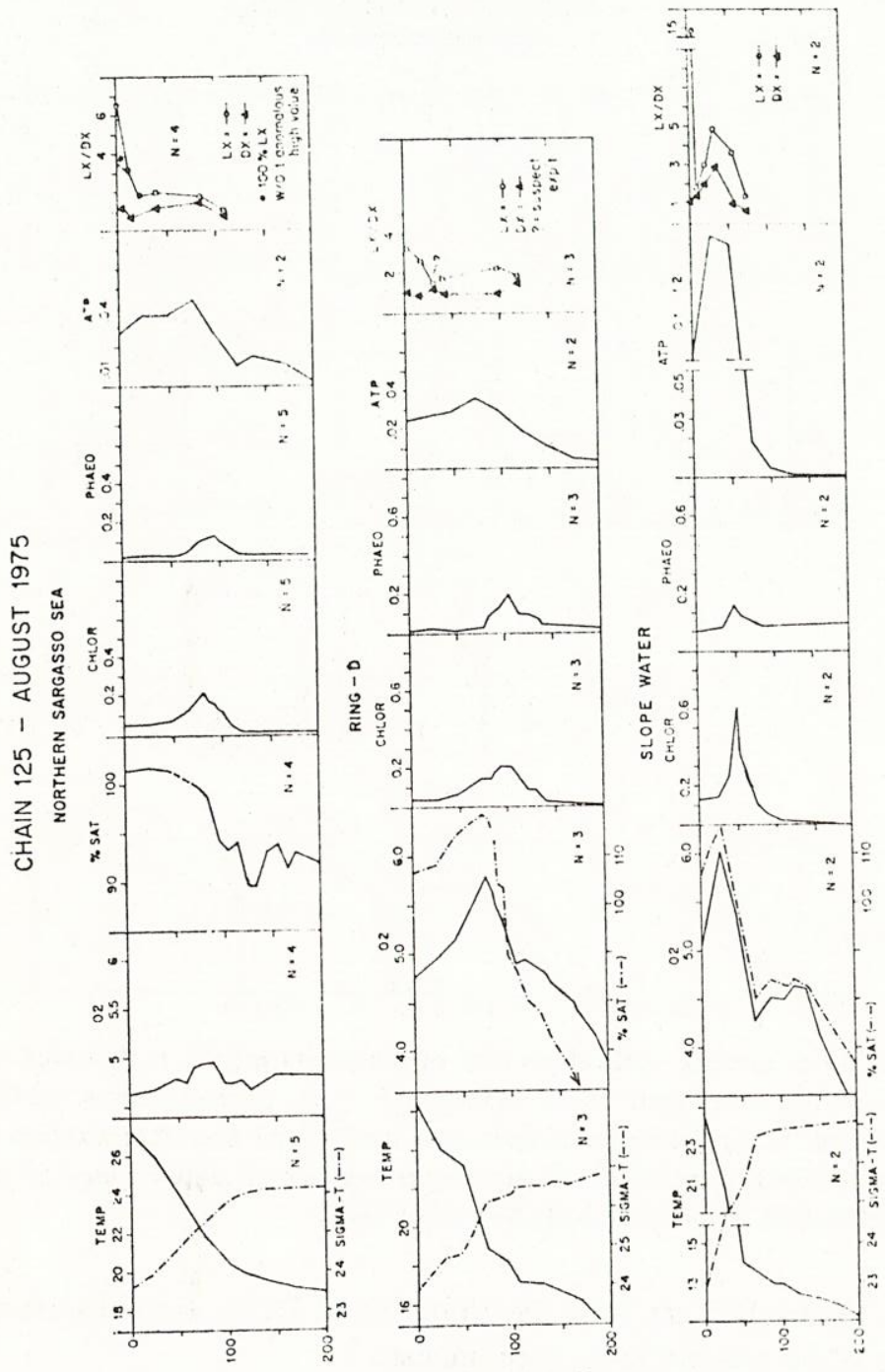

Figure 2. 0-200 m average vertical profiles of temperature $\left({ }^{\circ} \mathrm{C}\right) t$, dissolved oxygen $(\mathrm{ml} / \mathrm{l})$, percent saturation of oxygen (\%), chlorophyll (g/l), phaeopigments (g/l), ATP (g/l), light fixation of ${ }^{14} \mathrm{C}$ ( $\mathrm{g} \mathrm{C} / 1$ over a dawn-to-dusk incubation). R.V. Chain cruise 125, August 1975. $N$ equals the number of stations used in calculating the average profile.

particularly well-developed in the Slope Water stations where the density gradients were especially steep (Slope Water, $t / Z=.06$ ).

In August 1975, Northern Sargasso Sea, Ring D, and Slope Water stations ATP concentrations increased from the surface to the DCM and decreased beneath it. ATP concentration in the Northern Sargasso Sea had a minor minimum at the 


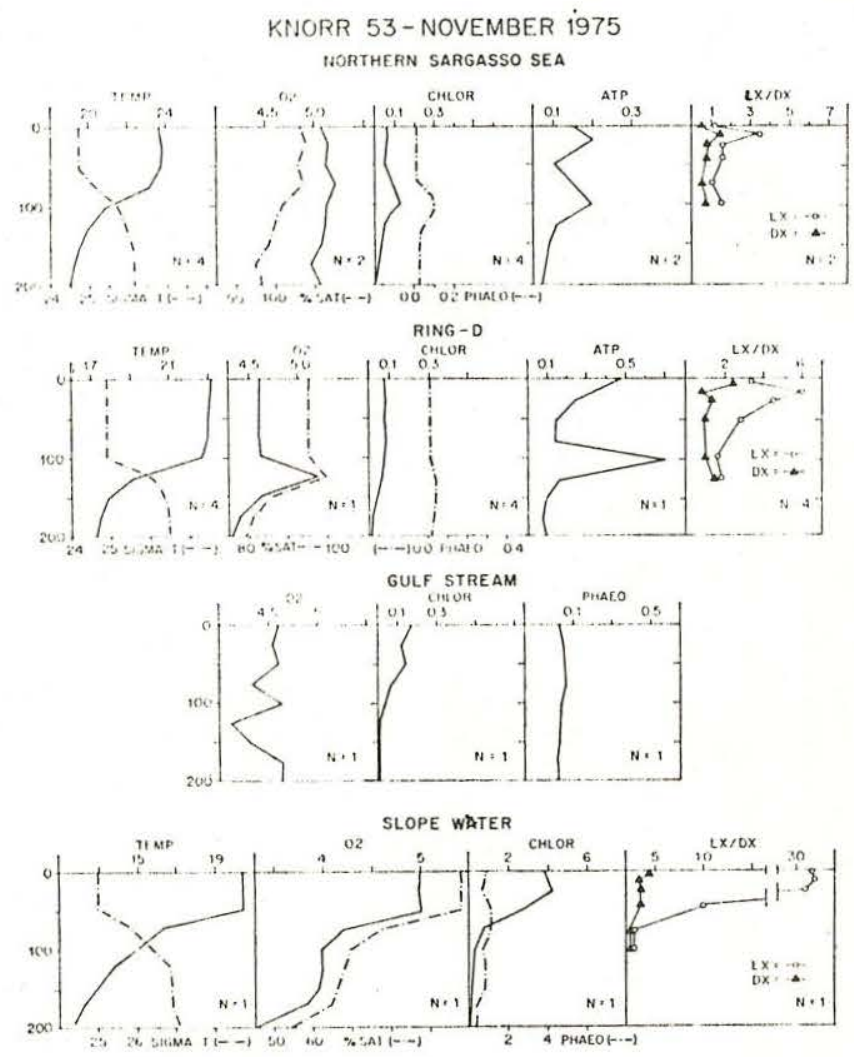

Figure 3. $\quad 0-200 \mathrm{~m}$ average vertical profiles of temperature $\left({ }^{\circ} \mathrm{C}\right) t$, dissolved oxygen $(\mathrm{ml} / \mathrm{l})$, percent saturation of oxygen $(\%)$, chlorophyll $(\mathrm{g} / \mathrm{l})$, phaeopigments $(\mathrm{g} / \mathrm{l})$, ATP $(\mathrm{g} / \mathrm{l})$, light fixation of ${ }^{14} \mathrm{C}$ ( $\mathrm{g} \mathrm{C} / \mathrm{l}$ over a dawn-to-dusk incubation) and dark fixation of ${ }^{16} \mathrm{C}(\mathrm{g} \mathrm{C} / 1$ over a dawn-to-dusk incubation). $N$ equals the number of stations used in calculating the average profile. R.V. Knorr cruise 53, November 1976.

same depth (about $125 \mathrm{~m}$ ). Like the Slope Water DCM, the subsurface ATP peak in the Slope Water was particularly prominent.

In Ring $\mathrm{D}$, both oxygen concentration and percent saturation were maximal in the middle of the stratified zone $(75 \mathrm{~m})$. At roughly the same depths, ${ }^{14} \mathrm{C}$ light fixation slightly increased. A similar relationship was observed in the Slope Water data. The Northern Sargasso Sea did not show a distinct subsurface oxygen maximum, but was supersaturated everywhere above the center of the DCM.

Between August 1975 and November 1975, the Northern Sargasso Sea had begun its winter overturn. In August 1975 (Fig. 2), uniform stratification extended from the surface to at least $100 \mathrm{~m}$ (e.g., $t / Z=.04,0-100 \mathrm{~m}$ ). By November 1975 (Fig. 3), mixing had erased the stratification of at least the upper $50 \mathrm{~m}(t / Z-.002$, $0-50 \mathrm{~m})$. This mixing was not yet sufficient to affect the DCM which was still 
within the deeper stratified layer. Oxygen saturation, ATP, and pigment profiles all were basically similar in August and November 1975. However, mixing had erased the slight $0-100 \mathrm{~m}$ dissolved oxygen gradient of increasing concentration observed in August 1975.

Between August and November 1975, Ring D also had begun its winter overturn (Fig. 3). Isothermal and isopyenal layers extended from the surface to at least $100 \mathrm{~m}$ (c.g., $t / Z=.001,0-100 \mathrm{~m}$ ) in contrast to the stratification of August (compare with Fig. 2). In November, dissolved oxygen concentration and saturation and chlorophyll were relatively uniform from 0-100 m. A subsurface dissolved oxygen maximum located just beneath a well-stratified layer $(t / Z-.05,100-125 \mathrm{~m})$ was not supersaturated. ${ }^{14} \mathrm{C}$ light fixation was higher in November than in August. In the only profile obtained, there was a prominent ATP maximum at about $100 \mathrm{~m}$ atop the well stratified layer.

Changes in the Slope Water between August and November 1975 paralleled the changes in Ring D. By November, mixing had proceeded sufficiently to produce isothermal and isopycnal conditions from the surface to at least $50 \mathrm{~m}$ (e.g., $t / Z=$ $.002,0-50 \mathrm{~m}$ in Slope Water). The DCM of August was erased and ${ }^{14} \mathrm{C}$ light fixation was much enhanced. Dissolved oxygen concentration was uniform within the mixed layer, and never supersaturated.

The following conclusions are drawn:

(1) Corroborating previous observations, a DCM occurred only after the formation of a stable shallow density gradient, typically marked by a seasonal thermocline. DCM depth was apparently dependent upon pycnocline depth, and was relatively predictable (within about $10 \mathrm{~m}$ ). Minor apparent regional differences in the relationships between $0-200 \mathrm{~m}$ profiles investigated could frequently be explained as sampling artifacts.

(2) Increasing chlorophyll concentration at the DCM did not, per se, indicate a proportional accumulation of plant biomass although on some occasions correlated peaks in the abundance of particular phytoplankton groups were noted (Ortner, et al., 1979). Oxygen profiles, nutrient profiles, and ${ }^{14} \mathrm{C}$ fixation experiments imply phytoplankton growth had occurred or was occurring at DCM depths. ATP profiles, dark ${ }^{14} \mathrm{C}$ fixation experiments and nutrient profiles imply microbial activity may have been enhanced at DCM depths (Ortner, 1978). In addition, both the correlation between the DCM and the seasonal thermocline, and the shape of the pigment profiles obtained, imply that DCM depths accumulated particulate matter sinking from above.

\section{Zooplankton results-August $\mathbf{1 9 7 5}$}

a. Total biomass. Zooplankton biomass data obtained from the MOCNESS and the Clarke-Bumpus tows in the Northern Sargasso Sea, Ring D, and the Slope 

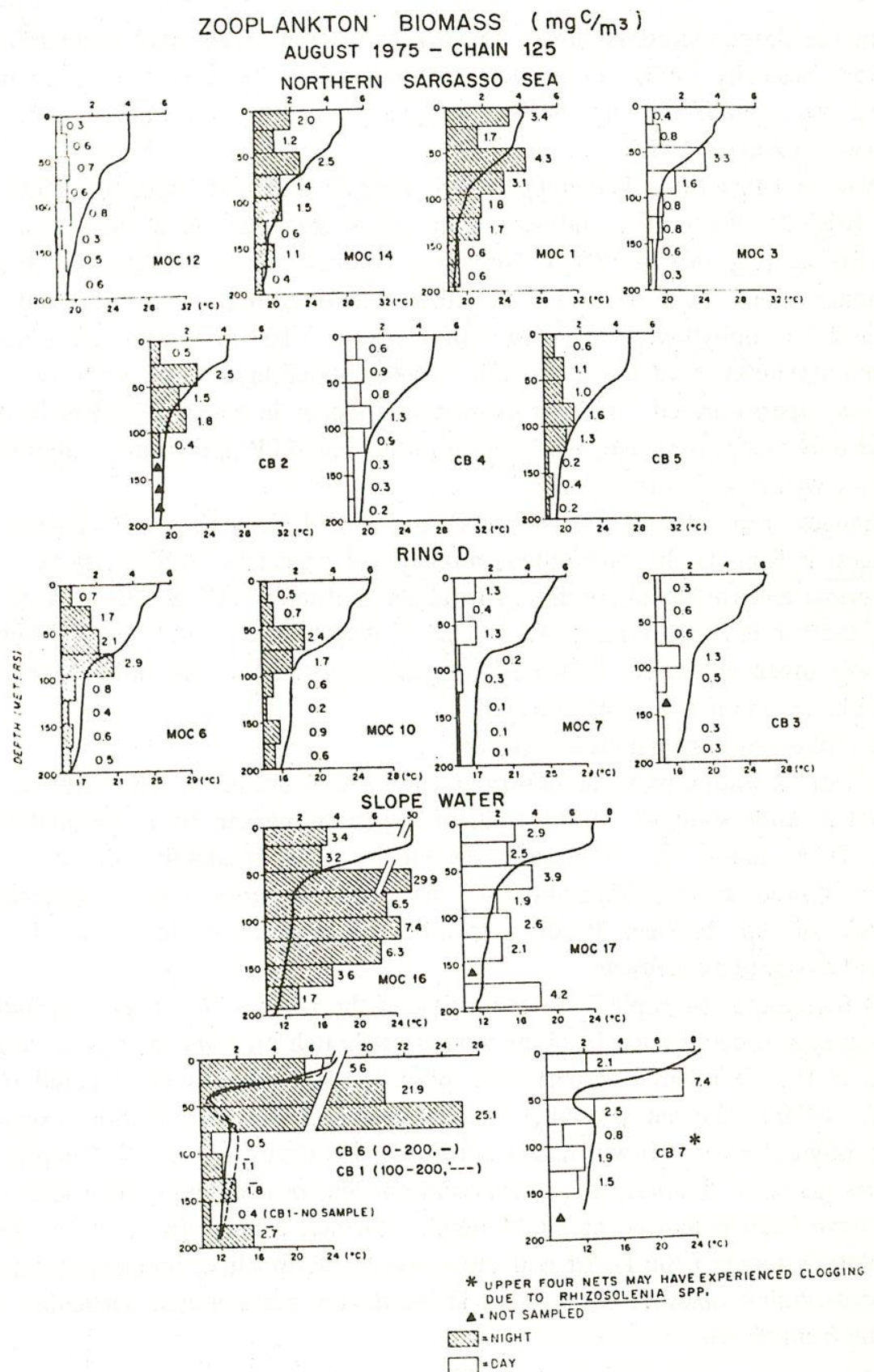

Figure 4. Zooplankton biomass $\left(\mathrm{mg} \mathrm{C} / \mathrm{m}^{3}\right)$. August 1975, R.V. Chain cruise 125 in the Northern Sargasso Sea, Ring D, and the Slope Water. MOCNESS and Clarke-Bumpus net tows. Values given are $\mathrm{mg} \mathrm{C} / \mathrm{m}^{3}$ over adjacent depth intervals. The $0-200 \mathrm{~m}$ temperature structure at the station or stations is superimposed on the biomass profile. 
Water in August 1975 are given in Figure 4. Day and night average 0-200 m biomass values $\left(\mathrm{MgC} / \mathrm{m}^{2}\right)$ in each region sampled were:

$\begin{array}{lccc} & \text { Northern Sargasso Sea } & \text { Ring D } & \text { Slope Water } \\ \text { CB-Day } & 132 & 100 & 480 \\ \text { CB-Night } & 174 & - & 1,478^{*} \\ \text { MOC-Day } & 163 & 95 & 581 \\ \text { MOC-Night } & 350 & 216 & 1,550^{*}\end{array}$

Starred samples, at least at some depths, were overwhelmingly dominated by salps. The biomass at those depths was calculated differently from that of the other samples (see Methods).

Biomass in Clarke-Bumpus day tows was not significantly different from biomass in MOCNESS day tows in the three regions sampled. For the Northern Sargasso Sea, there are day and night biomass estimates, calculated by the same method, for both types of gear. In that data, the night/day 0-200 m biomass ration, as determined by MOCNESS, was 2.15 . In contrast, the night/day $0-200 \mathrm{~m}$ biomass ratio was only 1.32 for Northern Sargasso Sea Clarke-Bumpus tows. In spite of this difference, there appears to be no systematic difference in relative vertical distribution between Clarke-Bumpus and MOCNESS tows (see Fig. 4). To obtain a sufficient number of samples to statistically test some of the vertical distribution patterns observed, the Clarke-Bumpus and MOCNESS data have been considered to represent one data set in the analyses that follow. Though Clarke-Bumpus and MOCNESS nets sampled different (though overlapping) size ranges of zooplankton, they both produced estimates of overall zooplankton biomass. If one net type tended to obscure vertical patterns of distribution because of size bias in sampling, the null hypothesis of no vertical difference in overall biomass distribution would tend to be accepted rather than rejected; hence, lumping of the two data sets is essentially a conservative procedure when testing the statistical significance of vertical biomass differences.

In most of the zooplankton biomass profiles, a subsurface peak occurred in the vicinity of the pycnocline and the DCM. The objective of the analysis which follows is to determine the statistical significance of the position of these peaks. The null hypothesis is that biomass values within a profile are, on the average, not significantly different.

Seven 0-200 m tows were taken in the Northern Sargasso Sea in August 1975 with MOCNESS and Clarke-Bumpus samplers (Fig. 4). Omitting CB2, because of its numerous missing values, and ranking the $25 \mathrm{~m}$ interval biomass estimates in the remaining six tows, the significance of the individual depth interval differences can be calculated by the method of Nemenyi (1963) without multiple-testing. This test, which employs ranks, prevents tows of higher overall biomass from dominat- 
ing the analysis. The most significant differences were as follows: $50-75$ biomass $>$ $125-150 \mathrm{~m},>150-175 \mathrm{~m}$, and $>175-200 \mathrm{~m}$ biomass; $75-100 \mathrm{~m}$ biomass $>$ $125-150 \mathrm{~m},>150-175 \mathrm{~m}$, and $>175-200 \mathrm{~m}$ biomass; $100-125 \mathrm{~m}$ biomass $>$ $175-200 \mathrm{~m}$ biomass $(p<.05)$. That is, $50-100 \mathrm{~m}$ biomass was significantly greater than biomass below. Though it cannot be shown with equal statistical rigor that $50-100 \mathrm{~m}$ biomass is greater than above, the figures strongly suggest that such is the case. The temperature profiles accompanying the biomass histograms indicate that $50-100 \mathrm{~m}$ bracketed the base of the seasonal thermocline in the Northern Sargasso Sea. It is suggestive that CB2, the top of the thermocline was more shallow than at any of the other stations and, at that station, an anomalously high $25-50 \mathrm{~m}$ biomass was observed.

Four 0-200 m MOCNESS and Clarke-Bumpus tows were taken in Ring D (Fig. 4). After interpolating to generate the single missing value in $\mathrm{CB} 3$, the significance of individual depth interval differences can be calculated as above. The most significant differences were as follows: $50-75 \mathrm{~m}$ biomass $>125-150 \mathrm{~m},>150-175$ $\mathrm{m}$, and $>175-200 \mathrm{~m}$ biomass; 75-100 $\mathrm{m}$ biomass $>175-200 \mathrm{~m}$ biomass $(p<.05)$. Our statistical approach is extremely conservative when the number of comparisons is small (here $N=$ only 4 ). If the level of significance is relaxed, then: $75-100 \mathrm{~m}$ biomass $>125-150 \mathrm{~m}$ and $>150-175 \mathrm{~m}$ biomass $(p<.10)$. In Ring $\mathrm{D}$, as in the Northern Sargasso Sea, 50-100 m biomass exceeds that above and below. Accompanying tempcrature profiles indicate that $50-100 \mathrm{~m}$ bracketed the base of the seasonal thermocline.

Two 0-200 m MOCNESS and three Clarke-Bumpus tows were taken in Slope Water (Fig. 4). CB6 and CB1 were combined into a composite profile with three of the histograms representing mean values. Since CB7 only sampled to $150 \mathrm{~m}$, it was decided to consider only the $0-150 \mathrm{~m}$ interval for statistical testing. The most significant biomass difference was $50-75 \mathrm{~m}$ biomass $>75-100 \mathrm{~m}$ biomass $(p<.05)$. Relaxing the level of significance: $50-75 \mathrm{~m}$ biomass $>100-125 \mathrm{~m}$ and $>$ $125-150 \mathrm{~m}$ biomass; $0-25 \mathrm{~m}$ biomass $>75-100 \mathrm{~m}$ biomass $(p<.10)$. The subsurface peak appears to be significant. In the Slope Water, the $50-75 \mathrm{~m}$ interval typically bracketed the base of the seasonal thermocline. Again, total biomass shows significant subsurface peaks centered about the seasonal thermocline.

b. Distribution of functional groups. The composition of the Clarke-Bumpus samples for August 1975 (Fig. 5) indicates that patterns in the distributions of particular zooplankton functional groups or taxa were consistent with patterns in the distribution of zooplankton biomass in the three areas investigated. Since these represent estimates of group abundances based on single tows, absolute numbers have to be interpreted with caution. However, there are consistent patterns recognizable from tow to tow which support the general conclusions resulting from the analysis of vertical biomass patterns. 


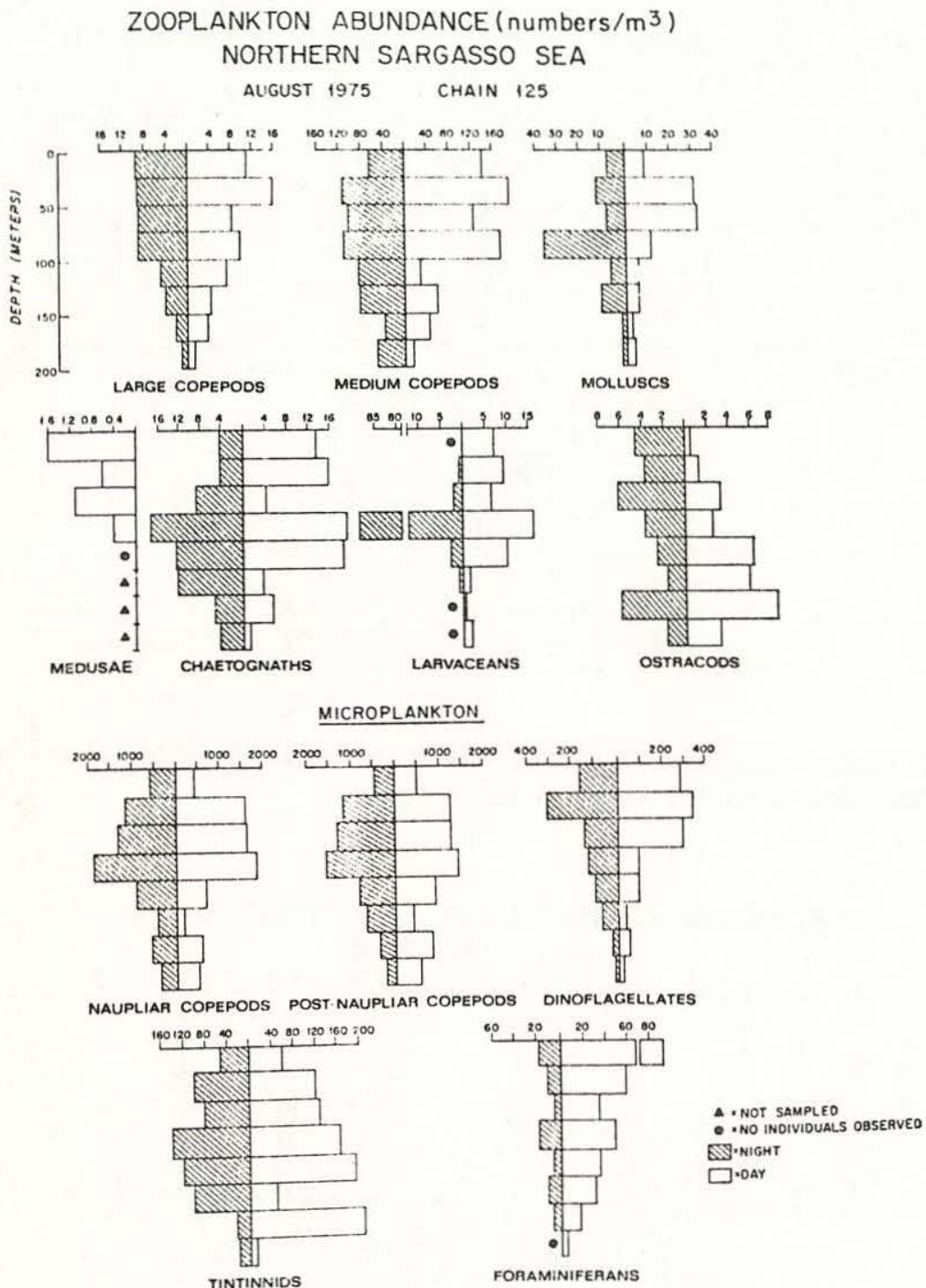

Figure 5. Vertical distribution of Northern Sargasso Sea zooplankton taxa and functional groups. August 1975, R.V. Chain cruise 125. Data from CB 4 (day), and both CB 2 and CB 5 (averaged to night value). Note that day and night tows do not necessarily represent a single sampling station.

Average zooplankton functional group or taxa abundance day and night in the Northern Sargasso Sea was determined from Clarke-Bumpus tows CB4, CB2, and CB5 (Fig. 5). In general, medium copepods, larvaceans, copepod developmental stages, molluscs and tintinnids seem to be concentrated around the $75-100 \mathrm{~m}$ depth interval. Medusae, dinoflagellates, foraminifera, and ostracods either show variable 


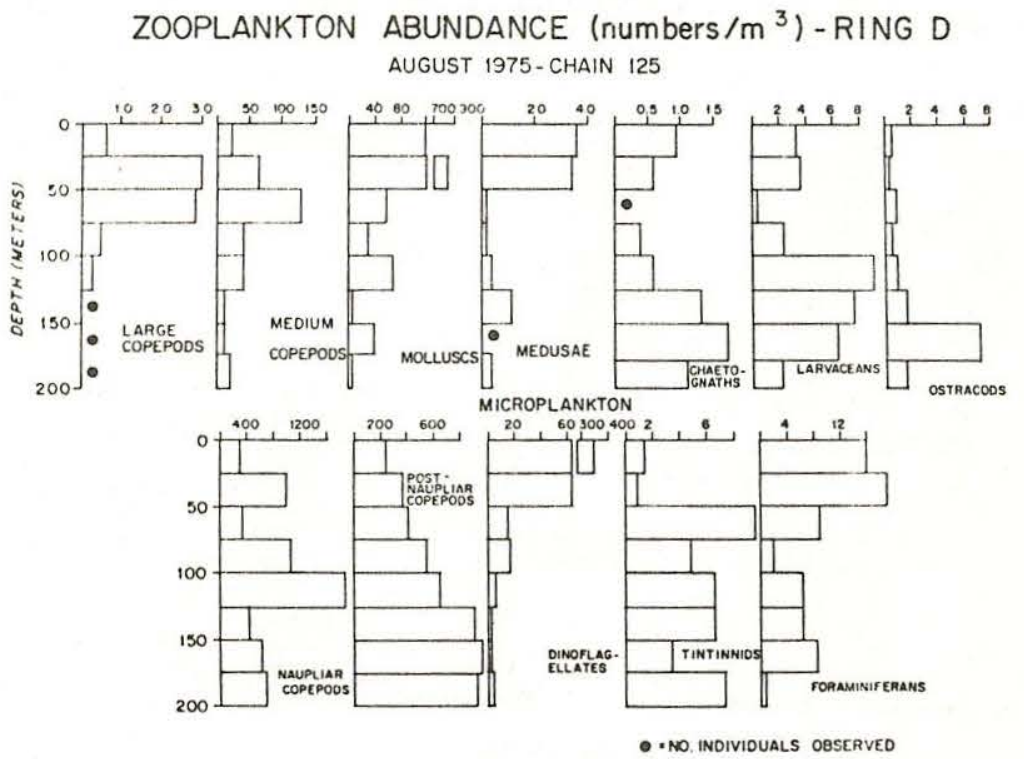

Figure 6. Vertical distribution of Ring D zooplankton taxa and functional groups. August 1975, R.V. Chain cruise 125. Data from CB 3 (day).

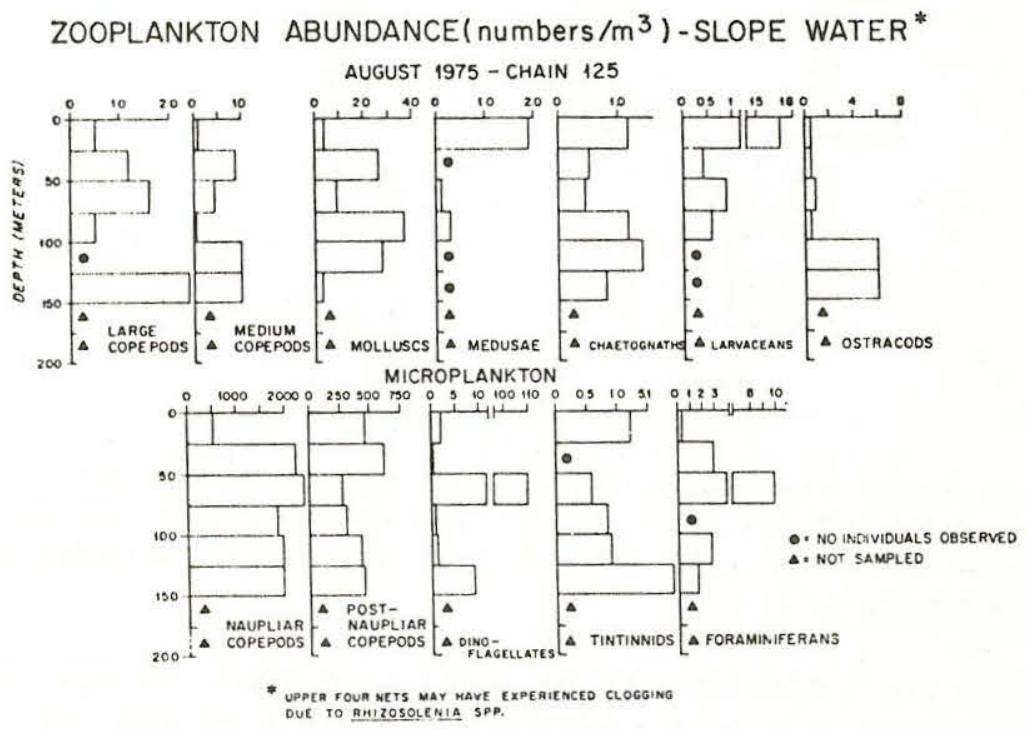

Figure 7. Vertical distribution of Slope Water zooplankton taxa and functional groups. August 1975, R.V. Chain cruise 125. Data from CB 7 (day). 
patterns or seem to be concentrated shallower in the water column. The single day tows available for August 1975 (Figs. 6 and 7) in Ring D and in Slope Water, indicates that there may be some differences in the similarity of depth occurrences among the groups as seen in the Sargasso samples. In Slope Water, larvaceans do not appear to be concentrated at DCM depths, and patterns in other groups are variable. In Ring D, larvaceans are associated with the DCM depths, but the center of distribution of other groups seems to be either shallower (medium and large copepods) or deeper (copepod developmental stages, ostracods).

\section{Zooplankton results-November 1975}

a. Total biomass. In November 1975, the upper water columns in these three regions experienced, to various degrees, the initiation of winter mixing. Thus, data from this cruise may permit evaluation of the strength of the relationship between vertical biomass structure and vertical temperature stratification (Fig. 8).

Interpolating missing values, day and night $0-200 \mathrm{~m}$ biomass values $\left(\mathrm{mgC} / \mathrm{m}^{2}\right)$ in MOCNESS and Clarke-Bumpus tows in each region sampled were:

$\begin{array}{lcrc} & \text { Northern Sargasso Sea } & \text { Ring D } & \text { Slope Water* } \\ \text { CB-Day } & 140.0 & 77.5 & 242.5 \\ \text { CB-Night } & 160.0 & 62.5 & 40.5 \\ \text { MOC-Day } & 165.0 & 55.0 & 365.0 \\ \text { MOC-Night } & 242.5 & 162.5 & 858.0\end{array}$

Examining the biomass peaks evident in the four Sargasso Sea tows (Fig. 8), the most significant differences were: $0-25 \mathrm{~m}$ biomass $>125-150 \mathrm{~m}$ biomass; $75-100$ $\mathrm{m}$ biomass $>125-150 \mathrm{~m}$ biomass $(p<.05)$. Less significant differences were: $0-25$ $\mathrm{m}$ biomass $>175-200 \mathrm{~m}$ biomass; $100-125 \mathrm{~m}$ biomass $>175-200 \mathrm{~m}$ biomass; $75-100 \mathrm{~m}$ biomass $>175-200 \mathrm{~m}$ biomass $(p<.10)$. A larger fraction of $0-200 \mathrm{~m}$ biomass was found near the surface in November 1975 than in August 1975. Despite this, there appeared to be a small, but definite, enhancement of biomass about the base of the seasonal thermocline in the Northern Sargasso Sea.

Four 0-200 m Clarke-Bumpus and MOCNESS tows were taken in Ring D (Fig. 8). The most significant difference was $75-100 \mathrm{~m}$ biomass $>175-200 \mathrm{~m}$ biomass $(p<.05)$. Less significant differences were: $75-100 \mathrm{~m}$ biomass $>100-125$ $\mathrm{m},>125-150 \mathrm{~m}$, and $150-175 \mathrm{~m}$ biomass; $0-25 \mathrm{~m}$ biomass $>175-200 \mathrm{~m}$ biomass, and 50-75 $\mathrm{m}$ biomass $>175-200 \mathrm{~m}$ biomass $(p<.10)$. As in the Northern Sargasso Sea, near-surface $(0-25 \mathrm{~m})$ biomass was relatively greater in November 1975 than in August 1975. Overall, 0-200 m biomass declined between August and November 1975 in Ring D at the Northern Sargasso Sea. Despite these changes, a minor concentration of biomass was noted at approximately the same depth as in August,

\footnotetext{
* Slope Water Clarke-Bumpus biomass values 0-100 m only.
} 


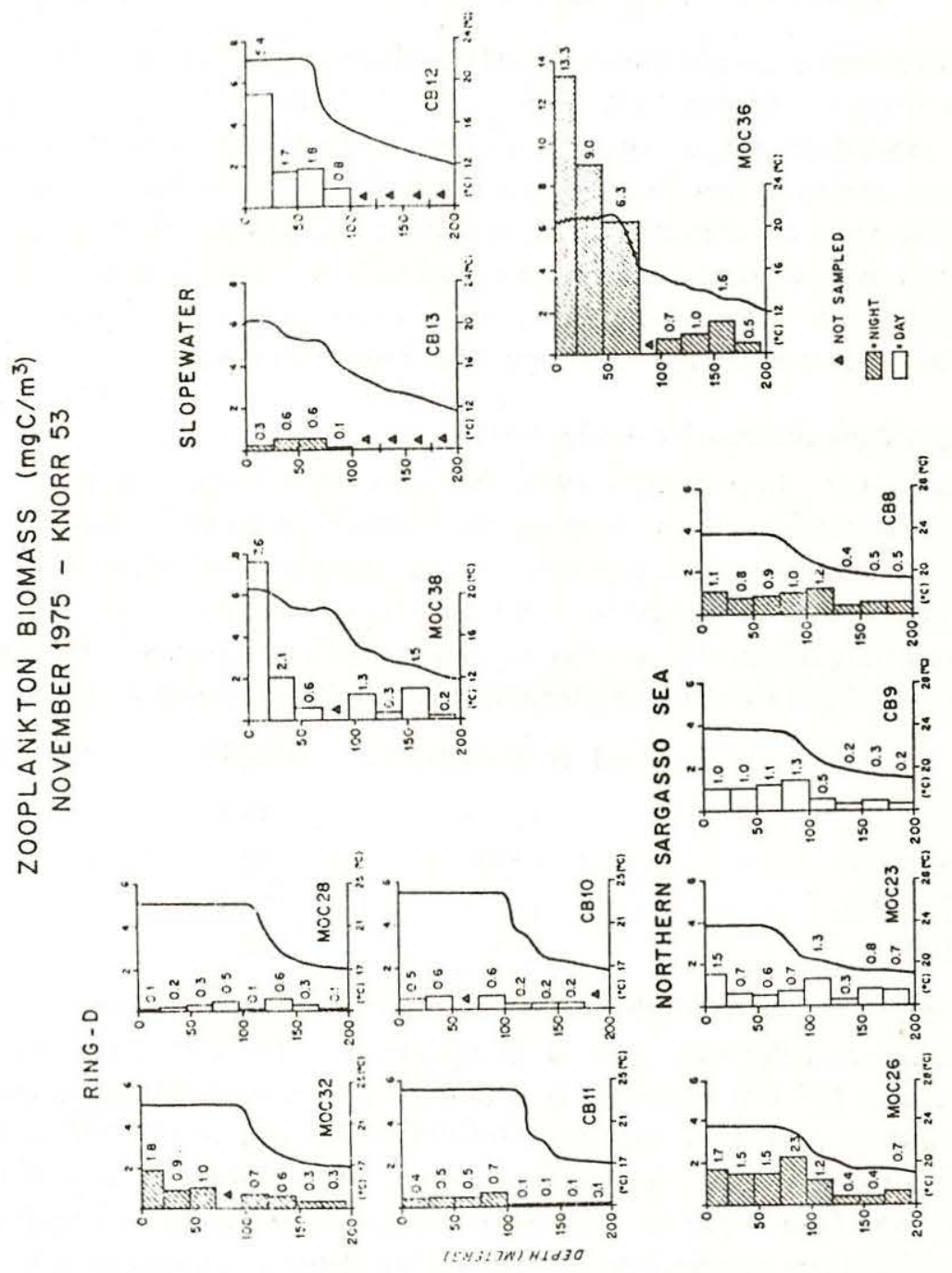

Figure 8. Zooplankton biomass $\left(\mathrm{mg} \mathrm{C} / \mathrm{m}^{2}\right)$. November 1975 , R.V. Knorr cruise 53. MOCNESS and Clarke-Bumpus net tows. Values given are $\mathrm{mg} \mathrm{C} / \mathrm{m}^{8}$ over adjacent depth intervals. The temperature structure at the particular station is superimposed on the biomass profiles.

but just above a seasonal thermocline in the process of erosion.

Four tows were taken in the Slope Water; two 0-200 m MOCNESS tows and two 0-100 m Clarke-Bumpus tows (Fig. 8). The significance of individual depth interval differences can be calculated as above if we consider only 0-100 m with $N=4$. The most significant interval differences were $0-25 \mathrm{~m}$ biomass $>75-100$ $\mathrm{m}$ biomass $(p<.05)$ and $25-50 \mathrm{~m}$ biomass $>75-100 \mathrm{~m}$ biomass $(p<.10)$. As in both the Northern Sargasso Sea and Ring D, the relative contribution of Slope 


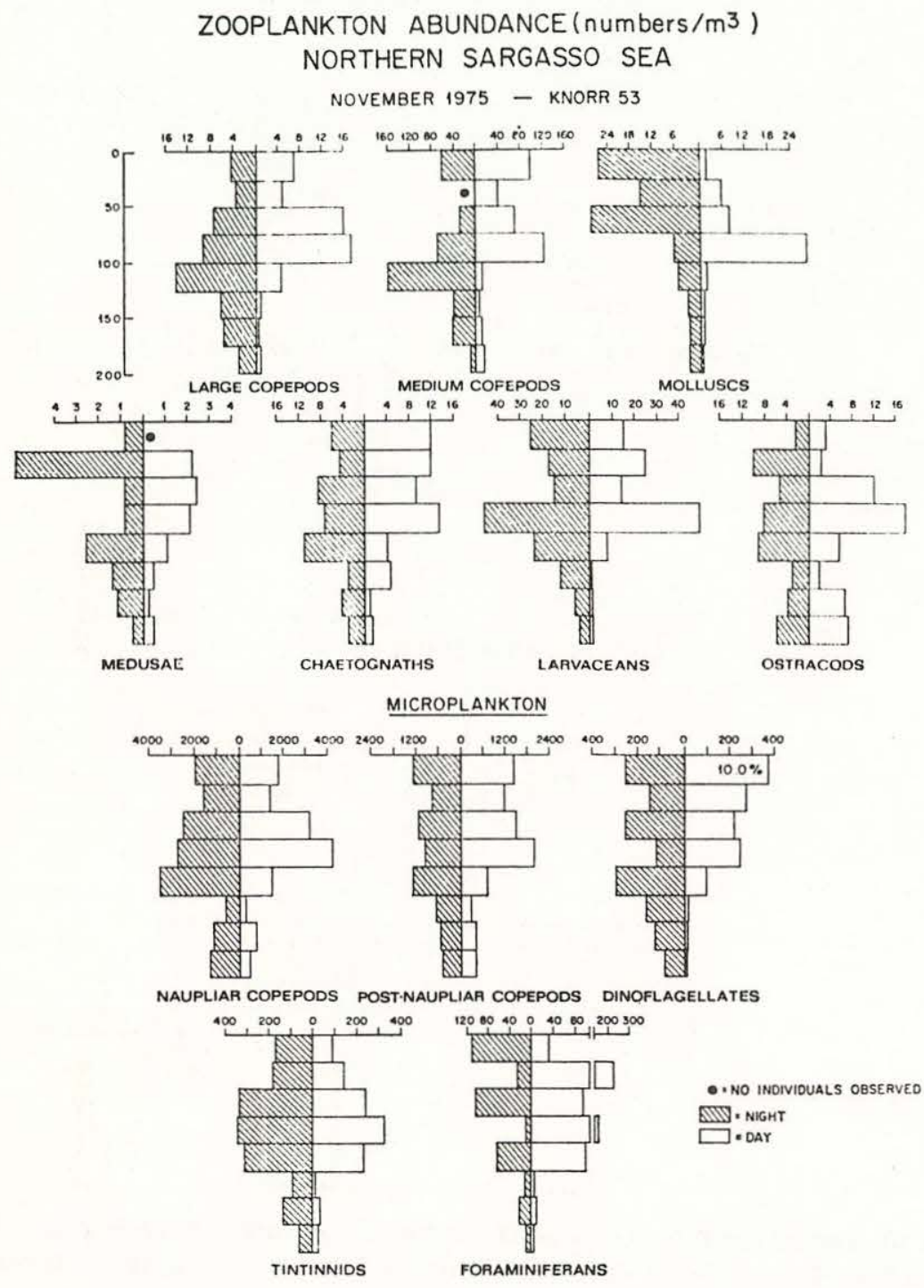

Figure 9. Vertical distribution of Northern Sargasso Sea zooplankton taxa and functional groups. November 1975, R.V. Knorr cruise 53. Data from CB 9 (day) and CB 8 (night). Note that day and night tows do not necessarily represent a single sampling station.

Water near-surface biomass was greater in November 1975 than in August 1975. On the average, biomass in November declined with depth and there was no trace of subsurface biomass maximum. Biomass declined sharply beneath an isothermal 0-50 m layer.

b. Distribution of functional groups. Analysis of particular functional groups of 


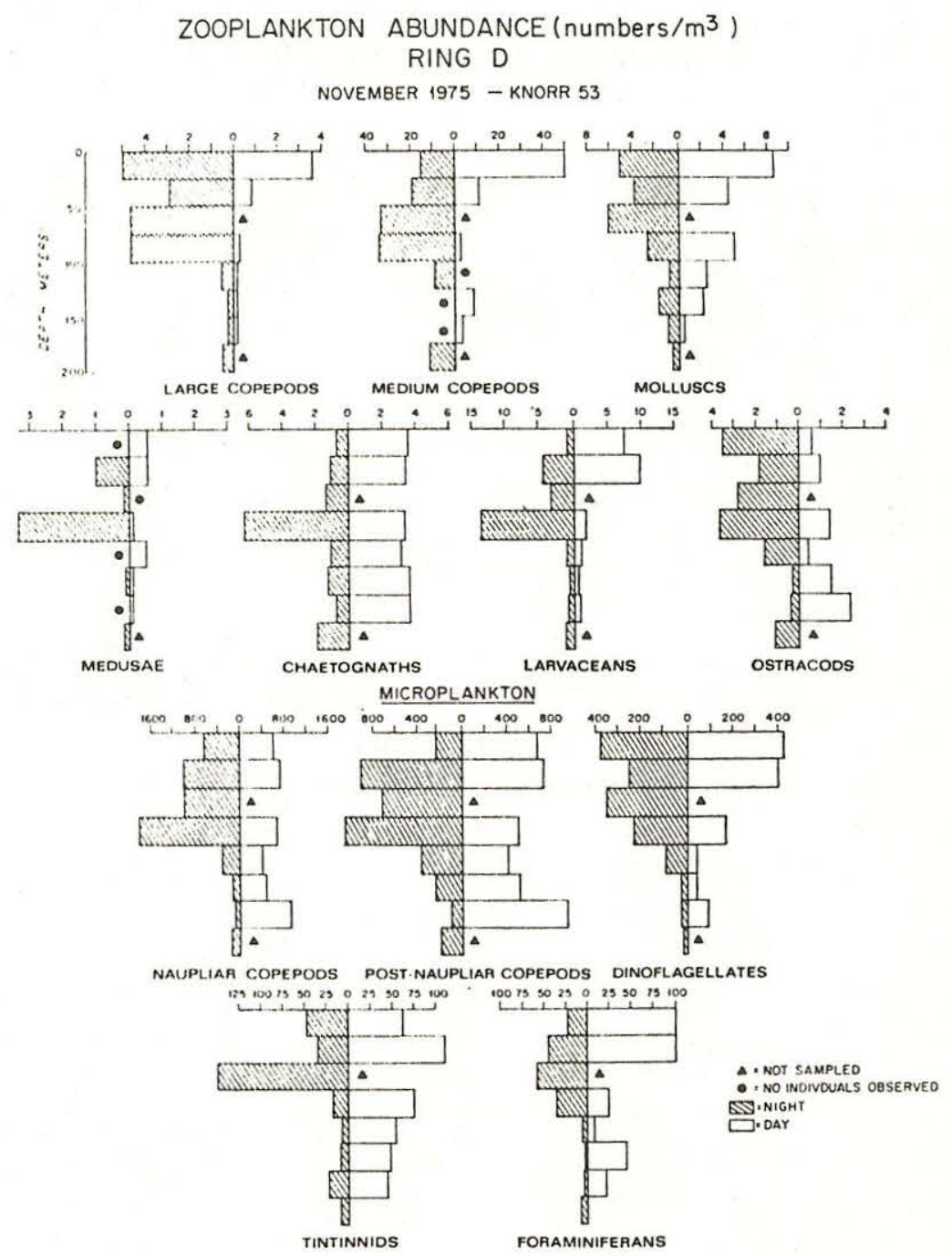

Figure 10. Vertical distribution of Ring D zooplankton taxa and functional groups. November 1975, R.V. Knorr cruise 53, data from CB 10 (day) and CB 99 (night). Note that day and night tows do not necessarily represent a single sampling station.

taxa indicates that community structure and vertical distribution in the Sargasso Sea may have changed between August and November. Large and medium copepods appeared to be more distinctly centered at a deeper maximum between 75-125 m (Fig. 9). Distributions of other groups did not appear to differ substantially from August patterns.

Ring D abundance patterns (Fig. 10) did not appear to change substantially except for the larvaceans, which appear to be almost exclusively confined to surface 


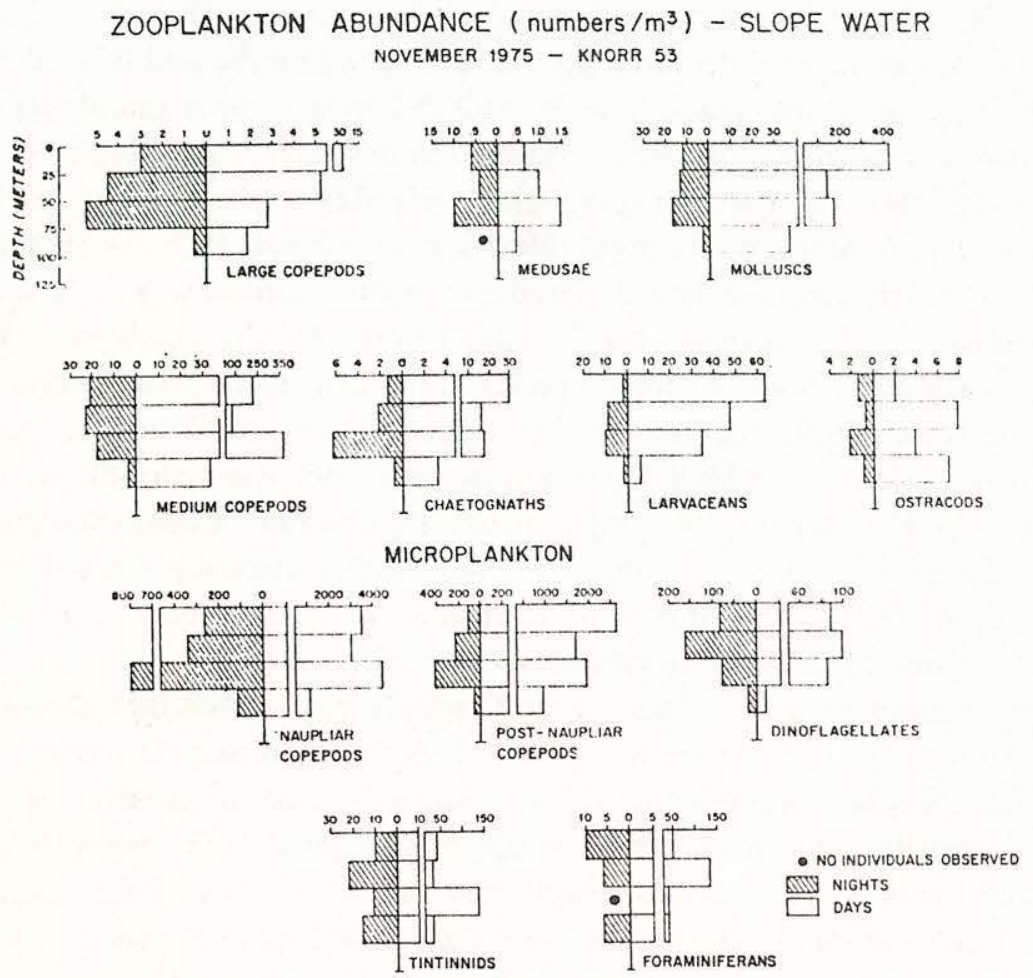

Figure 11. Vertical distribution of Slope Water zooplankton taxa and functional groups. November 1975, R.V. Knorr cruise 53. Data from CB 12 (day) and CB 13 (night). Note that day and night tows do not necessarily represent a single sampling station.

waters in the day, in contrast to the August day tow data. Subsurface numerical abundance peaks are particularly evident among medium copepods, medusae, chaetognaths, larvaceans, tintinnids, and copepod developmental stages, despite the lack of a well-defined chlorophyll maximum.

Slope Water (Fig. 11) showed a dramatic increase in abundances of groups by as much as an order of magnitude, though these differences may be due to possible clogging of the Clarke-Bumpus nets in August. Generally, the distribution of the larger animals appears to be shallower in November than in August.

\section{Discussion}

a. Sampling considerations. Prior to discussing the ecological significance of the results obtained, it is important to compare the samplers used in this study. Two very different types of gear were used: MOCNESS $(333 \mathrm{~m})$ and Clarke-Bumpus samplers (67 m mesh). They have given a similar picture of vertical 0-200 m biomass structure in the different regions sampled. Both documented systematic dif- 
ferences in Northern Sargasso Sea, Slope Water and Ring D biomass. However, day MOCNESS tows consistently contained less biornass than night MOCNESS tows, while day/night differences were both less systematic and less substantial in Clarke-Bumpus sample pairs. That is, MOCNESS day/night sample pairs clearly documented diel migration, while Clarke-Bumpus day/night samples did not. In some cases, this may reflect hydrographic variability at the same geographic location (see Fig. 6, Slope Water tows). However, in general, MOCNESS appeared to more adequately sample relatively large and mobile animals (e.g., euphausiids and pteropods) that, presumably, could avoid capture by the much smaller ClarkeBumpus samplers. Some of these species are known to be strong vertical migrators and their nightly presence in the upper $200 \mathrm{~m}$ contributed substantially to day/night differences in MOCNESS sample pairs, but minimally to day/night differences in Clarke-Bumpus sample pairs. In contrast, Clarke-Bumpus devices sampled a large number of small zooplankton, either underrepresented or not represented, in MOCNESS samples. In short, the two types of gear sampled partially different components of the zooplankton community.

The "microplankton", the part of the Clarke-Bumpus catch that almost certainly passed through the $333 \mathrm{~m}$ mesh of MOCNESS, included naupliar copepods, postanaupliar copepods, dinoflagellates, and tintinnids, and foraminiferans. Of these groups, naupliar and post-naupliar copepods dominated both microplankton numbers and biomass. This does not imply that the proportions of the microplankton in the Clarke-Bumpus samples represent their actual relative abundances. For example, one need only compare our numbers $/ \mathrm{m}^{3}$ of Northern Sargasso microplankton groups (Fig. 5) with the numbers $/ \mathrm{m}^{3}$ of North Pacific microplankton groups in Beers et al. (1975b) to realize that with $67 \mathrm{~m}$ mesh only the largest and least abundant individuals of most of those microplankton groups have been sampled. With the assumption that the size-frequency distribution of many of these forms does not systematically vary with depth, it is still possible to argue that qualitative conclusions can be drawn relative to the vertical distribution of microplankton. In fact, no such systematic variation was reported by Beers et al. (1975a) for their six North Pacific stations. A further indication that the above assumption may be warranted is that microzooplankton contribution to total zooplankton biomass was greater in Northern Sargasso Sea and Ring D samples than in Slope Water samples (Ortner, 1978); this direction of difference accords with similar observations made by Becrs and Stewart (1969) and Lebrasseur and Kennedy (1972).

$b$. The relationship of zooplankton biomass to the vertical temperature gradient. Overall zooplankton biomass in August 1975 has been shown to be significantly higher in $25 \mathrm{~m}$ depth intervals adjacent to, or encompassing the seasonal thermocline (Fig. 4). It is suggestive that in a Northern Sargasso Sea tow in which the mixed layer was particularly deep (compare CB5 and CB2 in Fig. 4) the biomass 
distribution was also particularly deep. On the other hand, naupliar and post naupliar copepods in Ring D were numerous primarily below the mixed layer (Fig. 6). Note that in both the Slope Water and Ring D increases in naupliar and post-naupliar copepod numbers occurred at approximately $20^{\circ}$ (compare temperature profile, Fig. 4, with abundance in Figs. 6 and 7). Although we have not examined the specific composition of this population, this suggests that the juvenile copepod population of Ring D may have been composed of Slope Water species entrained during ring formation since both Slope Water and Ring D populations appear to prefer temperatures $<20^{\circ} \mathrm{C}$. In the Slope Water, this strategy would position them in the maximum temperature gradient where food is relatively abundant. In Ring D, the same strategy seems less appropriate in that it separates the population from the chlorophyll $a$ maximum.

In November 1975, the hydrographic situation was quite different. The seasonal thermoclines in the Northern Sargasso Sea, Ring D, and the Slope Water either had been completely erased or were in the process of being eroded by the onset of winter mixing (temperature profiles in Figs. 3 and 6). Zooplankton biomass in the Northern Sargasso Sea still exhibited a small, but definite enhancement of biomass around the base of a deep but sharply defined seasonal thermocline. The Northern Sargasso Sea mixed layer was nearly isothermal, unlike in August and, in addition to the subsurface biomass maximum, there was a substantial surface, or near-surface biomass concentration. In Ring D, where mixing was more advanced, both the deep biomass maximum and the near-surface maximum were less definite. In the Slope Water, where mixing was the most advanced, no trace of a subsurface biomass maximum remained, surface concentrations were very high, and biomass was reasonably high everywhere above the remnant seasonal thermocline.

In November, naupliar and post-naupliar copepods had very different distributions than in August. Although subsurface maxima were noted in all regions at approximately the same depths as in August, surface values were relatively high in all regions. As noted earlier, although we have not examined the specific composition of these samples, the similarity of Ring D and Northern Sargasso Sea profiles suggests that the juvenile copepod population of Ring D may have been composed of Northern Sargasso Sea immigrants in November 1975.

c. Community structure at the subsurface biomass maximum. When the seasonal thermocline is well established, the most abundant phytoplankton cells in the Northern Sargasso Sea are quite small (Ortner et al., 1979). The fact that in August 1975 both medium and large copepod distributions in the Northern Sargasso Sea appear unrelated to the position of the seasonal thermocline and DCM (Fig. 5), suggests that the adult copepods sampled here did not appear to be utilizing the DCM as a major food resource. It is possible that inter-setal spaces within the feeding appendages of many of these forms may be too large to capture small 
particles efficiently. In contrast, larvaceans, molluscs, and some microzooplankton appeared, at the same time, to be concentrated about the DCM (Fig. 5). Due to their mode of feeding, these should be able to capture very small particles (Hamner et al., 1975; Becrs and Stewart, 1969). Chaetognaths, a purely carvinorous group relatively abundant in the Northern Sargasso Sea, also were concentrated at about the same depths. Their primary food may have been one or more of the above small, particle-fecding zooplankton groups.

In Slope Water, during August 1975, larvaceans, molluscs, and copepods of all sizes apparently had enhanced numbers at DCM depths (Fig. 7). This suggests that all of them may be able to utilize food available there. Although small cells still were abundant, larger cells were considerably more abundant in the Slope Water than in the Northern Sargasso Sea during the same season (Ortner et al., 1979). It is possible that a minimum density of phytoplankton is required for an adequate ratio to be obtained by the larger copepods. The data of Dagg (1977) and Mullin and Brooks (1977) suggests this may be the case.

In general, Ring D abundance patterns in August 1975 appeared similar to those of the Slope Water except for the fact that post-naupliar copepod numbers increased gradually with depth from the surface to $200 \mathrm{~m}$ (Fig. 6). The phytoplankton of Ring D in August, however, were more similar in composition to the surrounding Northern Sargasso Sea than to the Slope Water (Ortner et al., 1979). Further, Ring D total biomass had a subsurface maximum close in depth to that of the Northern Sargasso Sea.

Nearly all Northern Sargasso Sea functional groups had distributions centered about the DCM which had not yet been affected by fall mixing in November 1975 (Fig. 9). It is possible that the distribution of the larger copepods changed in part because food within the mixed layer had become so reduced after months of stratification as to induce a shift in feeding preference (Cowles, 1979).

In November 1975, Ring D 0-100 m numbers generally exceeded 100-200 m numbers (Fig. 10). Numbers increased at the considerably sharpened thermocline and most species groups showed a subsurface maximum. A DCM was no longer present, but an ATP maximum was still observed at approximately the seasonal thermocline. Further, with the onset of winter mixing, diatom numbers increased relative to August and ${ }^{14} \mathrm{C}$ fixation rates were higher (Ortner, 1978 and Ortner, et al., 1979). These changes may indicate that, prior to and during our sampling, more food was available throughout the mixed layer than in August 1975.

DCM structure had been largely erased in the Slope Water by November 1975 . Diatom abundance had markedly increased (Ortner et al., 1979). Day zooplankton abundances reflect these changes (Fig. 11). Numbers in most groups increased relative to August; yet, some groups still showed enhanced numbers at the permanent seasonal thermocline. These included tintinnids, nauplii, and medium copepods. 
In contrast, the night abundance patterns of nearly all groups show definite subsurface maxima at thermocline depths (Fig. 11). However, the water column sampled during the night tow was very different from that observed during the previous day (see temperature profiles, Fig. 6). Vertical mixing had been far less thorough, and the temperature structure of the night tow was much more similar to earlier August Slope Water profiles than to its "paired" November day tow.

d. Causal mechanisms for DCM/zooplankton association. For reasons discussed earlier, our interpretation of community structure is almost certainly biased because only the Clarke-Bumpus samples have been sorted. Further, sampling intervals of $25 \mathrm{~m}$ are clearly too broad, especially in the Slope Water (see Fig. 2) to precisely locate biomass or abundance peaks. All that has been strictly established is general co-occurrence of the DCM and zooplankton aggregations within depth intervals bracketing the seasonal thermocline. It did appear that, on some occasions, a distinguishable zooplankton assemblage was associated with the DCM and that the composition of this assemblage could be interpreted in light of the food available at those depths. The similarity of MOCNESS and Clarke-Bumpus biomass profiles indicated that a similar generalization might obtain for zooplankton groups inadequately sampled by the Clarke-Bumpus samplers. What are the causal mechanisms resulting in these distributions? Two major alternatives are apparent: relative availability of food, and physical structure in the upper water column. Bainbridge (1953) demonstrated that some herbivorous zooplankton species behave as if they perceive gradients in phytoplankton concentration and are, in fact, attracted to concentrations of particular species. Alternatively, the experiments of Harder (1968) and the field data of Boyd (1973) suggests that zooplankton are capable of sensing temperature gradients and may aggregate at those gradients in the absence of any other behavioral stimulus.

Data presented here do not resolve this difficult issue, but do shed some light on its complexity and suggest an approach which might resolve the issue. Clearly, in the summer, or when the DCM is well developed and stratification is most intense, food availability and physical structure are more or less coincident and cannot be separated. The fall data, however, suggest that with luck such a separation may be possible. Although, in some cases, the DCM had been erased by mixing, the subsurface zooplankton biomass maxima still was observed. The herbivorous species at that time could not have been behaving as in Bainbridge's experiments. Either they were exhibiting some habitual response, perhaps conditioned by prior biological interactions, or they were responding to the physical environmental gradient yet present. When herbivorous plankton have a vertical distribution apparently rclated to temperature structure, it is difficult to unambiguously interpret the codistribution of carnivorous species which might be responding to either the temperature gradient or the distribution of their prey. 
e. Historical context. To what extent do the results reported herein corroborate those of earlier investigators? Associations between zooplankton and seasonal deep chlorophyll maxima in near coastal environments have been documented by Mullin and Brooks (1972), Haury (1976), Anderson, et al. (1972) and Chester (1975). In more oceanic environments, microplankton/DCM associations have been reported by Beers and Stewart (1971), Hobson and Lorenzen (1972), and Gunderson et al. (1976). It is possible that the zooplankton microdistributions reported by Timonin (1976) in the tropical Pacific reflect a DCM/zooplankton association, although the phytoplankton of the depth intervals sampled were not assessed. It has been argued that the Central North Pacific may be dominated by in situ rather than advective processes and can, for much of the year, be considered to be in steady state (McGowan, 1977). In these respects, the Central North Pacific appears to be analogous to the Northern Sargasso Sea. Beers et al. (1975a) presented data for six Central North Pacific bottle casts in late June and observed that the numbers and biomass of micro-metazoans increased from 0-120 m. They observed no accumulation of phytoplankton cells at the DCM, which had been reported previously for the same region by Venrick et al. (1973). On the other hand, the latter authors found no concentration of zooplankton biomass $(>.035 \mathrm{~m}$ as sampled by a pump), and argued that a DCM could be accentuated if grazing pressure were more intense on the shallower phytoplankton. The same argument had earlier been made by Lorenzen (1967). No evidence for macrozooplankton aggregation at the Central North Pacific DCM has as yet been reported. Examinations of ZETES Expedition data reports (S.I.O. Reference 70-5) reveals no such association. In fact, there have been only a few documented cases of open ocean macrozooplankton/DCM associations (Longhurst, 1967; Youngbluth, 1975; perhaps Vinogradov et al., 1970; and Timonin, 1976). The set of observations reported here represents the only systematic documentation of substantial oceanic zooplankton biomass/DCM association. The reasons for this may be largely methodological. On an earlier occasion, we could not unambiguously demonstrate any association using Bongo nets (McGowan and Brown, 1966; data in Ortner, 1978).

There is at least one account of open ocean vertical zooplankton distribution which appears to contradict the results reported here (Longhurst, 1976). He presented extensive data obtained during EASTROPAC. His conclusion was similar to that of Lorenzen (1967); i.e., that zooplankton biomass and presumed grazing pressure are concentrated above the DCM perhaps at the depths where primary productivity is maximal. For the following reasons it is difficult to determine the reason for the difference between our conclusions.

All EASTROPAC data on chlorophyll, phytoplankton cell numbers, and ${ }^{14} \mathrm{C}$ uptake were obtained from bottle casts sampling at depths defined by percentages of ambient light and were, therefore, so widely spaced that it is virtually impossible 
to define the depths of maximal cell numbers or chlorophyll concentration (EASTROPAC Atlas).

Biases in the LHPR profiles present an additional difficulty. Haury et al. (1976), documented a number of sources of bias in LHPR results, most of which result in variable time lags between introduction into the filtering cone and appearance on the recording gauze. Their analysis, unfortunately unavailable until well after EASTROPAC, suggests that, given the conditions described by Longhurst, i.c., recorder box design, gauze advance time, length of tow, direction of tow, etc., biases may have occurred in EASTROPAC LHPR tows. Since only upward oblique hauls were taken during EASTROPAC, these sources of error could skew actual distributions to shallower depths. Such problems could not have occurred using either MOCNESS or Clarke-Bumpus samplers because in both cases the entire filtering cone opens and closes at specific depths. While the tow rejection criteria used in Longhurst (1976) are valid and rightfully eliminate some spurious tows, they would not have been able to detect these systematic biases.

While behavioral cues abound to account for zooplankton aggregation about the DCM, it is difficult to imagine cues which would permit zooplankters to detect gradients in the rate of ${ }^{14} \mathrm{C}$ incorporation by phytoplankton, though the possibility of associated chemical gradients or "taste" criteria cannot be discounted. In short, it is impossible at this time to satisfactorily determine the degree to which Longhurst's (1976) data are contradictory to those reported here. If they are, they may indicate fundamental differences in the structure of the plankton communities of the eastern Tropical Pacific and the western North Atlantic. Data we recently obtained in the Panama Basin (Pacific) and in the Southern Sargasso (Atlantic) suggest there may well be fundamental differences between the seasonal DCM of the western North Atlantic and the permanent DCM of the tropics.

Acknowledgments. We gratefully acknowledge the assistance given by Loren Haury, Alfred Morton, John Wormuth, Christopher Polloni, and Steve Boyd in making the collections at sea and the skillful operation of the R.V. Knorr and R.V. Chain by their officers and crew. Thanks are also due to Michael Stroman for assistance in the laboratory analyses and data processing and to Jane Peterson for secretarial services. This study was supported by N0001466-C0241 NR083-004; N00014-74-C0262 NR083-004 and National Science Foundation grant DES 74-02783A1, the Woods Hole Oceanographic Institution Graduate Education Program and the Tai Ping Foundation. Contribution No. 4249 from the Woods Hole Oceanographic Institution (WHOI), Woods Hole, MA 02543. This paper contains material from P. Ortner's Ph.D. thesis.

\section{REFERENCES}

Ahlstrom, E. H. and J. R. Thrailkill. 1963. Plankton volume loss with time of preservation. Calif. Coop. Oceanic Fish. Invest. Rep., 9, 57-93.

Anderson, G. C., B. W. Frost, and W. K. Peterson. 1972. On the vertical distribution of zooplankton in relation to chlorophyll concentrations, in Biological Oceanography of the Northern North Pacific Ocean, A. Y. Takenouti, et al., Eds. Idemitsu Shoten, 626 pp. 
Bainbridge, R. 1953. Studies on the interrelationships of zooplankton and phytoplankton. J. Mar. Biol. Assoc. U.K., 32, 385-445.

Beers, J. R. and G. L. Stewart. 1967. Microzooplankton in the euphotic zone at five locations across the California Current. J. Fish. Res. Bd. Canada, 24, 2053-2068.

- 1969. The vertical distribution of microzooplankton and some ecological observations. J. du Cons. perm. Explor. Mer, 33, 30-44.

Beers, J. R. and G. L. Stewart. 1971. Macrozooplankters in the plankton communities of the upper water of the eastern Tropical Pacific. Deep-Sea Res., 18, 861-883.

Beers, J. R., F. M. H. Reid, and G. L. Stewart. 1975a. Microplankton of the North Pacific Central Gyre. Population structure and abundance, June 1973. Int. Rev. Ges. Hydrobiol., 60, 607-638.

- 1975b. Microplankton in the central gyre of the North Pacific Ocean. Part 1. Population structure and abundance, June 1973. Inst. Mar. Res. Ref. 75-6, 195 pp.

Boyd, C. M. 1973. Small-scale spatial patterns of marine zooplankton examined by an electronic in situ zooplankton detecting device. Netherlands J. Sea Res., 7, 103-111.

Brown, N. L. 1974. A precision CTD microprofiler. Proceedings of the International Conference on Engineering in the Ocean Environment. Halifax, Nova Scotia, 2, 220-278.

Chester, A. J. 1975. Ciliate microzooplankton distribution relative to a sub-surface chlorophyll maximum off the Washington coast. U. Wash., Master's thesis, $81 \mathrm{pp}$.

Cowles, T. J. 1979. The feeding response of copepods from the Peru Upwelling System: food size selection. J. Mar. Res., 37, 601-622.

Dagg, M. 1977. Some effects of patchy food environments on copepods. Limnol. Oceanogr., 22, 99-107.

EASTROPAC Atlas. 1972. U.S. Dept. of Commerce, NOAA Circular 330, vol. 1, June 1972.

Fairbanks, R. G., P. H. Wiebe and A. W. H. Be. 1980. Vertical distribution and isotopic composition of living planktonic foraminifera in the western North Atlantic. Science, 207, $61-63$.

Gunderson, K. R., J. S. Corbin, C. L. Hanson, M. L. Hanson, R. B. Hanson, D. J. Russel, A. Stollar, and O. Yamada. 1976. Structure and biological dynamics of the Oligotrophic Ocean photic zone off the Hawaiian Islands. Pacific Science, 30, 45-68.

Hamner, W. M., L. P. Madin, A. L. Alldredge, R. W. Gilmer, and P. O. Hamner. 1975. Underwater observations of gelatinous zooplankton: sampling problems, feeding biology, and behavior. Limnol. Oceanogr., 20, 907-917.

Harder, W. 1968. Reactions of plankton organisms to water stratification. Limnol. Oceangr., 13, 156-168.

Haury, L. R. 1976. Small-scale pattern of a California current zooplankton assemblage. Mar. Biol., 37, 137-157.

Haury, L. R., P. H. Wiebe, and S. H. Boyd. 1976. Longhurst-Hardy Plankton Recorders: their design and use to minimize bias. Deep-Sea Res., 23, 1-15.

Hobson, L. A. and C. J. Lorenzen. 1972. Relationships of chlorophyll maxima to density structure in the Atlantic Ocean and Gulf of Mexico. Deep-Sea Res., 19, 297-306.

Lebrasseur, R. J. and O. D. Kennedy. 1972. Microzooplankton coastal and oceanic areas of the Pacific Subarctic water mass: a preliminary report, in The Biology of the Indian Ocean, B. Zeitzschel and S. A. Gerlach, Eds. Springer, 549 pp.

Longhurst, A. R. 1967. Vertical distribution of zooplankton in relation to the eastern Pacific oxygen minimum. Deep-Sea Res., 14, 51-63. 
1976. Interactions between zooplankton and phytoplankton profiles in the eastern Tropical Pacific Ocean. Deep-Sea Res., 23, 729-754.

Lorenzen, C. J. 1967. Vertical distribution of chlorophyll and phaeopigments: Baja, California. Deep-Sea Res., 14, 735-745.

McEwen, G. F., M. W. Johuson, and T. R. Folsom. 1954. A statistical analysis of the performance of the Folsom plankton sample splitter, based upon past performances. Arch. Meterol. Geophys. Bio. Ser. A., 7, 502-523.

McGowan, J. A. and D. W. Brown. 1966. A new opening-closing paired zooplankton net. Scripps Inst. Oceanogr. Ref. 66-23: 1-56.

McGowan, J. 1977. What regulates pelagic community structure in the Pacific? in Oceanics Sound Scattering Prediction, N. R. Anderson and B. Zahuranec, Eds., Plen. Press, N.Y., 859 pp.

Mullin, M. M. and E. R. Brooks. 1972. The vertical distribution of juvenile Calanus (Copepoda) and phytoplankton within the upper $50 \mathrm{~m}$ of water off La Jolla, California, in Biological Oceanography of the Northern North Pacific Ocean, A. Y. Takenouti, et al., Eds., 626 pp.

- 1977. Some consequences of distributional heterogeneity of phytoplankton and zooplankton. Limnol. Oceanogr., 21, 784-796.

Nemenyi, P. 1963. Distribution-free multiple comparisons. Ph.D. Dissertation, Princeton University, $127 \mathrm{pp}$.

Ortner, P. B. 1978. The seasonal deep chlorophyll maximum in the western North Atlantic and its significance to regional food chain relationships. Woods Hole Oceanographic Institution, Technical Report 78-59: 219 pages plus appendices.

Ortner, P. B., P. H. Wiebe, L. Haury, and S. Boyd. 1978a. Variability in zooplankton biomass distribution in the Northern Sargasso Sea: the contribution of Gulf Stream cold core rings. Fish. Bull., 76, 323-334.

Ortner, P. B., E. M. Hulburt, and P. H. Wiebe. 1979. Gulf Stream rings, phytohydrography and herbivore habitat contrasts. Jour. Exp. Mar. Biol. and Ecol., 39, 101-124.

Silver, M. E. W. 1971. The habitat of Salpa fusiformis in the California Current as defined by stomach content studies and the effect of salp swarms on the food supply of the plankton community. Ph.D. thesis, Scripps Inst. Oceanogr., Univ. Calif., San Diego.

Timonin, A. G. 1976. Study of the vertical microdistribution of oceanic zooplankton. Oceanology, 16, 79-82.

Venrick, E. L., J. A. McGowen, and A. W. Mantula. 1973. Deep maxima of photosynthetic chlorophyll in the Pacific Ocean. Fish. Bull., 71, 41-52.

Vinogradov, M. E., I. I. Gitelzon, and Yu. I. Soroken. 1970. The vertical structure of a pelagic community in the tropical ocean. Mar. Biol., 6, 187-194.

Wiebe, P. H., S. Boyd, and J. Cox. 1975. Relationships between zooplankton displacement volume, wet weight, dry weight, and carbon. Fish. Bull., U.S., 73, 777-786.

Wiebe, P. H., K. H. Burt, S. Boyd, and A. W. Morton. 1976. A multiple opening/closing net and environmental sensing system for sampling zooplankton. J. Mar. Res., 34, 313-326.

Wiebe, P. H., L. P. Madin, G. R. Harbison, L. R. Haury, and L. M. Philbir. 1979. Diel vertical migration by Salpa aspen and the potential for large-scale particulate organic matter transport to the deep-sea. Mar. Biol., 53, 249-255.

Youngbluth, M. J. 1975. The vertical distribution and diel migration of euphausiids in the central waters of the eastern South Pacific. Deep-Sea Res., 22, 519-536. 

MANDATORY DISTRIBUTION LIST

FOR UNCLASSIFIED TECHNICAL REPORTS, REPRINTS, AND FINAL REPORTS PUBLISHED BY OCEANOGRAPHIC CONTRACTORS

OF THE OCEAN SCIENCE AND TECHNOLOGY DIVISION

OF THE OFFICE OF NAVAL RESEARCH

(REVISED NOVEMBER 1978)

1 Deputy Under Secretary of Defense (Research and Advanced Technology)

Military Assistant for Environmental Science Room 3D129

Washington, D.C. 20301

Office of Naval Research

800 North Quincy Street

Arlington, VA 22217

3 ATTN: Code 483

1 ATTN: Code 460

2 ATTN: 102B

1 CDR J. C. Harlett, (USN)

ONR Representative

Woods Hole Oceanographic Inst.

Woods Hole, MA 02543

Commanding Officer

Naval Research Laboratory

Washington, D.C. 20375

6 ATTN: Library, Code 2627
12 Defense Documentation Center Cameron Station

Alexandria, VA 22314

ATTN: DCA

Commander

Naval Oceanographic Office NSTL Station

Bay St. Louis, MS 39522

ATTN: Code 8100

ATTN: Code 6000

ATTN: Code 3300

1 NODC/NOAA

Code D781

Wiscons in Avenue, N.W.

Washington, D.C. 20235 
UNCLASSIFIED $4 / 81$

SECURITY CLASSIFICATION OF THIS PAGE (When Date Entered)

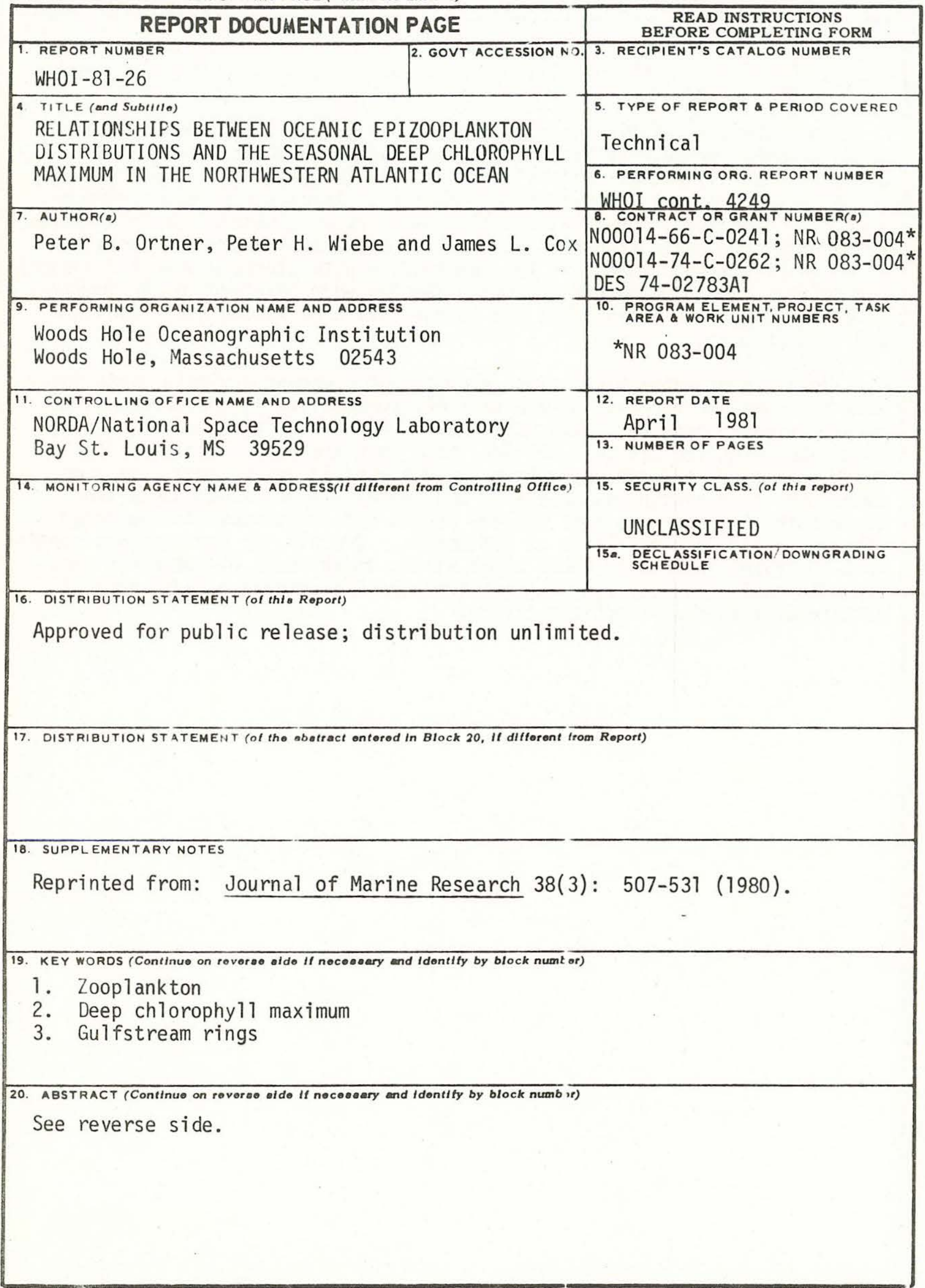


\#20.

The potential significance of the Deep Chlorophyll Maximum (DCM) as a fond resource for pelagic food chains was studied in three hydrographic regilies of the Northwestern Atlantic Ocean: the Slope Water, the Northern Sargasso Sea and a Gulf Stream cold core ring. Samples for phytoplankton species, chlorophy11 and related water chemistry were obtained with a series of water bottle casts from the upper $200 \mathrm{~m}$; microzooplankton and macrozooplankton were also obtained in the upper $200 \mathrm{~m}$ with Clarke Bumpus (67 m mesh) and MOCNESS (333 m mesh) net systems. Samples were obtained in the summer when the DCM was well developed and in the fall when mining had erased the $\mathrm{DCl}$ in most areas.

Total zooplankton biomass was significantly enhanced within depth intervals including or adjacent to the seasonal thermocline in the three hydrographic areas. Hydrocast data show the DCM in these regions was predictably associated with the seasonal thermocline. Thus these data indicate zooplankton biomass was enhanced about the DCM when it was present. In some cases, the zooplankton assemblage at DCM depths was distinguishable from those both at deeper and more shallow depths and its composition appeared related to the food available at DCM depths. Overal1, in environments ranging from moderately rich near-shore Slope Waters to the more oligotrophic openocean Sargasso Sea, our data suggest that the DCM signals a depth zone of particularly intense trophic activity. 


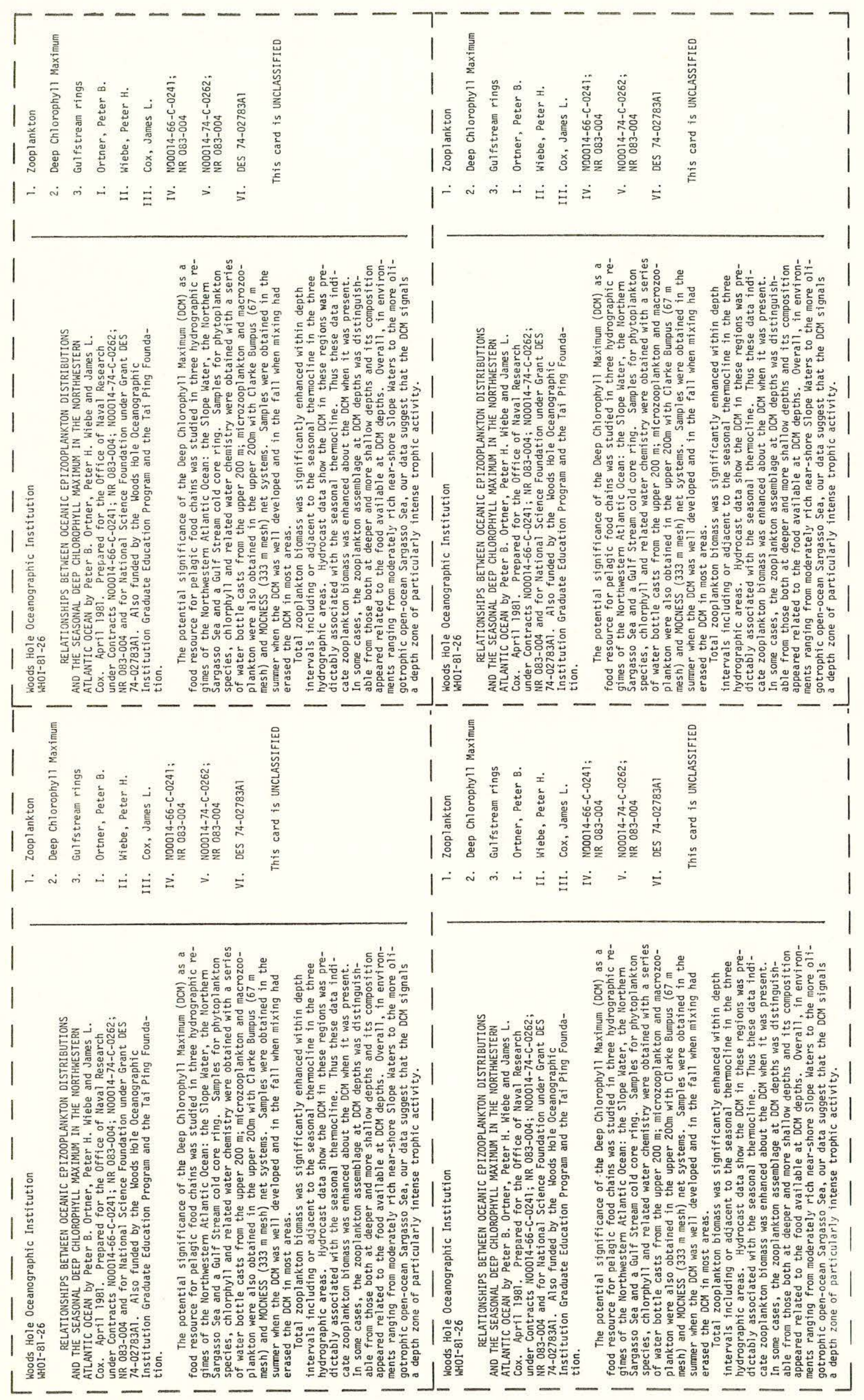

